\title{
Enhancing Students' Ability in Listening to Lectures Through TQLR (Tune in, Question, Listen, Review) Strategy Assisted by Youtube Videos
}

\author{
Imelda Darmayanti Manurung \\ ${ }^{1}$ University of Muhammadiyah Sumatera Utara, Medan, Indonesia, $ه$ (email) imeldadarmayanti@umsu.ac.id
}

\begin{abstract}
This study was carried out to improve the students' ability in listening to lectures due to the students' difficulties in learning this listening material. Therefore, a classroom action research by applying TQLR (Tune In, Question, Listen, Review) strategy assisted with You Tube Videos was done to solve those problems. The subject of this research is the VI-B1 class of English Education Department of FKIP UMSU which consists of 38 students. A mix method is used to analyze the data obtain. Listening test in form of multiple choice tests was administrated for pre-test and post-test in each cycle. The results of the test shows that the students' ability in listening to lectures was significantly improve. In addition, based on the students' answer on questionnaire given, using of lecturing videos taken from You Tube is also increasing the students' interest in learning this subject.
\end{abstract}

Keywords: Listening, Lectures, TQLR Strategy, You Tube, Video

\section{INTRODUCTION}

Listening is a process to understanding what is going to listen to and determine the information needed in accordance with the purpose of listening itself. Therefore, to be a good listener, he should mastering the listening skills itself. A listener should be able to gather information, understand the information given, doing interpretation, and determining the appropriate action based on the listening results. A listener not only should have a good auditory but also the ability to interpret the message, and do repetition to ensure the message given (Manurung, 2019). In addition, a listener must also have extensive background experience and knowledge so that he understands all the listening material that come from diverse backgrounds in the field of science with all forms of discourse. Thus, a listener is not expected to face significant difficulties in understanding what he listens to. This is very necessary in listening to the advanced level, one of which is listening to lectures.

Listening to lectures is one of the sub competencies taught in advanced listening classes in semester VI of the English Language Education Study Program at Muhammadiyah University, North Sumatra. In this lesson, students learnt to understand a variety of scientific texts with duration of 1.50 - 3 minutes. They were expected to comprehend and answer the questions given. At the end of the lesson, students expected to be able to obtain specific information that stated both explicitly and implicitly in the oral text played, get detailed information from public lectures, presentations, and / or reports, compare and evaluate the contents or messages in the text. They can not achieved this purpose if they only hope for face-to-face meetings because of the limited time and number of meetings. Therefore, the use of appropriate strategies and media is important to achieve the listening goals themselves. Ekayati (2016) states that to achieve maximum learning goals, a student should have awareness and independence in learning and not only depends on the material provided by the lecturer.

TQLR strategy is one of the strategies that can used to achieve the above objectives. This strategy consists of four stages; Tune in (prepare to listen and determine the topic to be heard), Question (predict questions that will arise), Listen (listen carefully and filter the information needed), Review (evaluate the messages obtained, intent and its usefulness based on the questions given). The aims of this strategy are to use and improve the access to prior knowledge, facilitate and expand understanding of the knowledge acquired, simplify and shorten the time to do work, build awareness for learning so as to improve academic transfer skills, explore new learning by developing questions which can improve students' ability to focus on learning, develop personal control of the situation, and strengthen language development (Collier, 2016). Herlina (2019) proves this strategy can improve students' learning abilities in listening comprehension lessons and there are significant differences in learning outcomes between students taught and not taught with this strategy. This also support by Fruarsih (2012), that the ability to listen to students who was taught using TQLR is higher than those who are not also supports this.

In maximalizing the using of teaching strategy, an appropriate leaning media is needed as a tools aid to deliver the material in a better way and also to attract the 
students motivation and interest in engaging the teaching learning activity (Manurung, Yusriati, \& Husni, 2019). Thus why the using of media also has a significant influence on learning outcomes in listening (Li, 2012). The use of audiovisual media in listening learning can also improve students' listening abilities and make the learning process more enjoyable (Noviyanti \& Manurung, 2018). So, along with current technological developments, the use of video as an audiovisual media originating from the You Tube page is highly recommended as an authentic and easily accessible learning resource, especially in learning foreign languages in the classroom (Kelsen, 2009). The use of You Tube in teaching can positively increase student and teacher participation (Kabooha \& Elyas, 2018). In line with this, Almurashi (2016) also proven that You Tube can be used as a learning resource that can help students understand the lessons given especially in English lessons. The use of videos from You Tube both outside and inside the classroom can improve speaking, listening, and breathing skills (Watkins \& Wilkins, 2011).

Therefore, this study aimed to describe the enhancement of the students' listening ability in listening to lecture through TQLR strategy assisted by You Tube videos. It is expected can add the new perspectives of teaching listening strategy by implemented social media as tools aid.

\section{METHOD}

This study conducted in English Education Department of University of Muhammadiyah Sumatera Utara and focuses on the students on the sixth semester that took advanced listening subject that distributes into six classes. By using purposive sampling technique, 38 students of B morning class were chosen as the subject of this research. Kemmis and Taggart's classroom action research design is implemented to reach the goal of this research, improving the students' listening ability in listening to lectures. The implementation was done in two cycles. The steps of each cycle were consists of planning, action, observation, and reflection.

A mix method was applied in analyzing the data of this study. In order to gain the quantitative data for analyzing the students improvement in listening to lectures, four set of multiple choice tests was administered to the students in each cycle at pre-test and post-test. The test was taken from Longman Preparation Course for the TOEFL Test 2003 by Deborah Philips, part C, due to the learning objective of the listening subject and the standard competencies that students should reach. The test was consists of 12 questions with 3 mini lectures with 2-3 minutes duration. A set of observation sheet, diary notes, and questionnaire was used to measure the qualitative data and also to supervise whether the teaching learning scenario did well. The students' final score of each test is used to compare the students' ability before and after the application of the learning strategy and evaluate the success of the application. Here are the steps of analyzing data:
1. Scoring the test

2. Categorize the students' listening ability based on the criteria below

Table 1.Ability Categorization

\begin{tabular}{ccc}
\hline $\begin{array}{c}\text { Quantitative } \\
\text { Ability }\end{array}$ & $\begin{array}{c}\text { Qualitative } \\
\text { Ability }\end{array}$ & Ability \\
$90-100$ & excellent & able \\
\hline $80-89$ & very good & able \\
\hline $70-79$ & good & able \\
\hline $60-69$ & fair & able \\
\hline $50-59$ & poor & unable \\
\hline$\leq 49$ & very poor & unable \\
\hline \multicolumn{4}{r}{ Table based on UMSU's scoring system 2015 }
\end{tabular}

3. Categorize the students learning completeness based on the criteria below

Table 2. Learning Completeness Criteria

\begin{tabular}{cccl}
\hline \multicolumn{2}{c}{ Score Scale } & Remarks \\
\cline { 1 - 2 } Qualitative & Quantitative & \\
\hline $85-100$ & A & $\begin{array}{l}\text { Passed } \\
\text { Complete }\end{array}$ \\
\hline $80-84$ & A- & $\begin{array}{l}\text { Passed } \\
\text { Complete }\end{array}$ \\
\hline $75-79$ & B+ & $\begin{array}{l}\text { Passed } \\
\text { Complete }\end{array}$ \\
\hline $70-74$ & B & $\begin{array}{l}\text { Passed } \\
\text { Complete }\end{array}$ \\
\hline $65-69$ & B- & $\begin{array}{l}\text { Passed } \\
\text { Complete }\end{array}$ \\
\hline $60-64$ & C + & $\begin{array}{l}\text { Passed } \\
\text { Complete }\end{array}$ \\
\hline $55-59$ & C & $\begin{array}{l}\text { Passed } \\
\text { Incomplete }\end{array}$ \\
\hline $50-54$ & D & $\begin{array}{l}\text { Fail } \\
\text { Incomplete }\end{array}$ \\
\hline$\leq 49$ & E & $\begin{array}{l}\text { Fail } \\
\text { Incomplete }\end{array}$ \\
\hline
\end{tabular}

Table based on UMSU's scoring system 2015

The objectives of learning were success if one of these indicators is fulfilled:

1. The learning implementation reached $\geq 70 \%$,

2. Students' learning completeness $\geq 70 \%$,

3. The problems that arise in teaching learning process can be overcome

4. Describing the condition of learning process in listening to lectures by using TQLR strategy assisted by You Tube Videos based on the analyzing of qualitative data obtaining from observation sheet and questionnaire.

\section{RESULTS AND DISCUSSION}

Data obtained in pre-test and post-test of each cycle was analyzed to describe how is the improvement of the students' listening ability in learning listening to lectures by applying the TQLR strategy assisted by You Tube 
videos. The students were taught by using this strategy in two cycles due to the indicators for the success of objective learning itself which was unfulfilled in first cycle, the learning implementation and the students' learning completeness still $\leq 70 \%$. In line, the students were also facing difficulties in tune in their background knowledge for each topic of lectures given in first cycle. Thus make them unable to find the detail information and answer the inferential questions. Therefore, this application was continued to cycle two. The data of the students' test score in each cycle can be drawn in general as followed.

Before applying the strategy, the students were given a pre-test. The result of the pre-test was used as a guidance to arrange the teaching learning scenario and preparing the material based on the standard competence of listening to lectures unit. In addition, the pre-test data show the students' mean score only 35.7 with maximum score 66.7 and minimum score 16.7 , while the score range is $0-100$. Next, the strategy was applied; the first cycle is run down. After two meetings applying this strategy, posttest is given to the students to measure if there is an improvement or not. The result shown that there was an improvement which was shown from the rising of students' score compare with the pre-test score. In this post-test of cycle I, the students' mean score was 55.7, the increasing is 20 points. It is also followed by the increasing of maximum score 83.3, and minimum score 25.An observation was done to this cycle; a reflection shows that most of the students were unfamiliar with the text being played. Thus made they feel difficult in getting detail and meaning of the text. They missed most of the important point of the information in the lectures and this made the cycle should be continued to the next cycle.

In cycle two, pre-test also given to the students to measure whether their ability is still the same as in previous cycle. The data shown that there is no significant regression; the mean score is 3.3 lower. Then before the plans continue, the students were asked to find out some references to the topic of lecture related to the text theme to enrich their background of knowledge and vocabulary. At last, on post-test, the students' mean score is rise into 70.8 with maximum score is 91.7 and minimum score 41.7. The improvement also seen from the enhancement of the students' total score; 1358 in pre-test become 2116.7 in post-test I, then rise into 2691.7 at post-test II. The increasing of the students' test score in each cycle was presented in the table 3 .

Table 3.The Students' Test Score

\begin{tabular}{lcccc} 
Criteria & \multicolumn{2}{c}{ Cycle I } & \multicolumn{2}{c}{ Cycle II } \\
\cline { 2 - 5 } & Pre-test & Post-test & Pre-test & Post-test \\
& 1 & 1 & 2 & 2 \\
\hline Mean & 35.7 & 55.7 & 52.4 & 70.8 \\
\hline Max & 66.7 & 83.3 & 75 & 91.7 \\
\hline Min & 16.7 & 25 & 25 & 41.7 \\
\hline Total & 1358.3 & 2116.7 & 1991.7 & 2691.7 \\
\hline
\end{tabular}

Another improvement is also can be seen from the rising of the students' ability in listening to lecture from cycle I to cycle II. In this pre-test, only 3 from 38 students or $7.9 \%$ were categorized able, which means $92.1 \%$ of the students, are not able in this subject. Next, in post test of cycle I, it was increase into 13 students or $34.2 \%$, and reached 31 students or $81.6 \%$ at the end of cycle II. The increasing of students' listening ability was clearly shown in the table 4 and summarized below.

Table 4.The Students' Ability in Listening to Lectures

\begin{tabular}{|c|c|c|c|c|c|c|}
\hline \multicolumn{2}{|c|}{ Score Scale } & \multicolumn{2}{|c|}{ Cycle I } & \multicolumn{2}{|c|}{ Cycle II } & \multirow{2}{*}{$\begin{array}{c}\text { Abilit } \\
\mathrm{y}\end{array}$} \\
\hline $\begin{array}{l}\text { Quantitati } \\
\text { ve }\end{array}$ & $\begin{array}{c}\text { Qualitati } \\
\text { ve }\end{array}$ & $\begin{array}{c}\text { Pre } \\
- \\
\text { test } \\
1\end{array}$ & $\begin{array}{c}\text { Post } \\
\text {-test } \\
1\end{array}$ & $\begin{array}{c}\text { Pre } \\
- \\
\text { test } \\
2\end{array}$ & $\begin{array}{c}\text { Post } \\
\text {-test } \\
2\end{array}$ & \\
\hline $90-100$ & excellent & 0 & 0 & 0 & 2 & able \\
\hline $80-89$ & $\begin{array}{l}\text { very } \\
\text { good }\end{array}$ & 0 & 2 & 0 & 6 & able \\
\hline $70-79$ & good & 0 & 4 & 2 & 14 & able \\
\hline $60-69$ & fair & 3 & 7 & 7 & 9 & able \\
\hline $50-59$ & poor & 6 & 16 & 20 & 5 & $\begin{array}{c}\text { unabl } \\
\mathrm{e}\end{array}$ \\
\hline$\leq 49$ & $\begin{array}{l}\text { very } \\
\text { poor }\end{array}$ & 29 & 9 & 9 & 2 & $\begin{array}{c}\text { unabl } \\
\mathrm{e}\end{array}$ \\
\hline
\end{tabular}

The chart below presents the significant increasing of the students' listening ability. The number of unable students was decreased in each test.

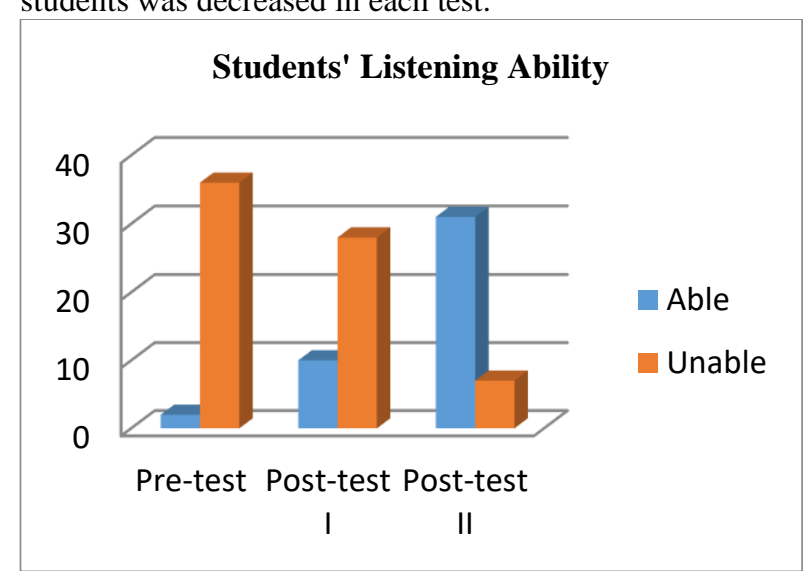

Figure 1. The Students' Achievement in Listening to Lectures

The next indicator which is indicate the enhancement of the listening ability is the improvement of the students' achievement in each cycle based on the percentage of the students who reach passed complete remarks. An increase of the number of students who reach the minimum standard completeness criteria (KKM) shows that the teaching learning process is well done and achieves the goal of the learning process itself. The achievement itself where categorized into three; passed complete, passed incomplete, and fail incomplete. Passed complete means that the students are allowed to continue to the next lesson, while passed incomplete means they are 
Table 5.The Students' Achievement in Listening to Lectures

\begin{tabular}{ccccccc}
\hline \multicolumn{2}{c}{ Score Scale } & \multicolumn{2}{c}{ Cycle I } & \multicolumn{2}{c}{ Cycle II } & Remarks \\
\hline Quantitative & Qualitative & Pre-test 1 & Post-test 2 & Pre-test 2 & Post-test 2 & \\
\hline $85-100$ & A & 0 & 0 & 0 & 2 & Passed Complete \\
\hline $80-84$ & A- & 0 & 2 & 0 & 6 & Passed Complete \\
\hline $75-79$ & B + & 0 & 4 & 2 & 14 & Passed Complete \\
\hline $70-74$ & B & 0 & 0 & 0 & 0 & Passed Complete \\
\hline $65-69$ & B- & 3 & 7 & 7 & 9 & Passed Complete \\
\hline $60-64$ & C + & 0 & 0 & 0 & 0 & Passed Complete \\
\hline $55-59$ & C & 2 & 7 & 6 & 3 & Passed Incomplete \\
\hline $50-54$ & D & 4 & 16 & 14 & 2 & Fail Incomplete \\
\hline$\leq 49$ & E & 29 & 9 & 9 & 2 & Fail Incomplete \\
\hline
\end{tabular}

allowed to follow the next lesson after taken remedy, and fail incomplete means that they are not allowed to follow the next lesson and should repeat the previous lesson given. Based on the data obtain, in pre-test only 3 from 38 students or $7.9 \%$ who categorized passed complete, 2 students $(5.3 \%)$ passed incomplete, and 33 students or $86.8 \%$ of the students, are not able in this subject. This fact indicated a suitable teaching strategy need to apply to repair this condition. After applying the TQLR strategy assisted by You Tube videos, a significant progress were shown in each cycle. Based on the students score in posttest I of cycle I, 13 students or $34 \%$ were categorized passed complete. It means there was an improvement as much as $26.1 \%$. This condition is still unfulfilled the perquisite the indicator in reaching the learning objectives. Therefore this teaching activity continued to the next cycle. After evaluate the teaching learning process and done some improvements on the learning scenarios, the post test of cycle II indicate a significant enhancement, 33 students or $86.8 \%$ passed complete this lesson. It met the indicators, students learning completeness $\geq 70 \%$; the objective of learning is achieved. The progress of the students' learning achievement in each cycle was presented in the table 5 .

The improvement of the students' listening achievement based on the minimum standard completeness criteria clearly drawn in Figure 2.

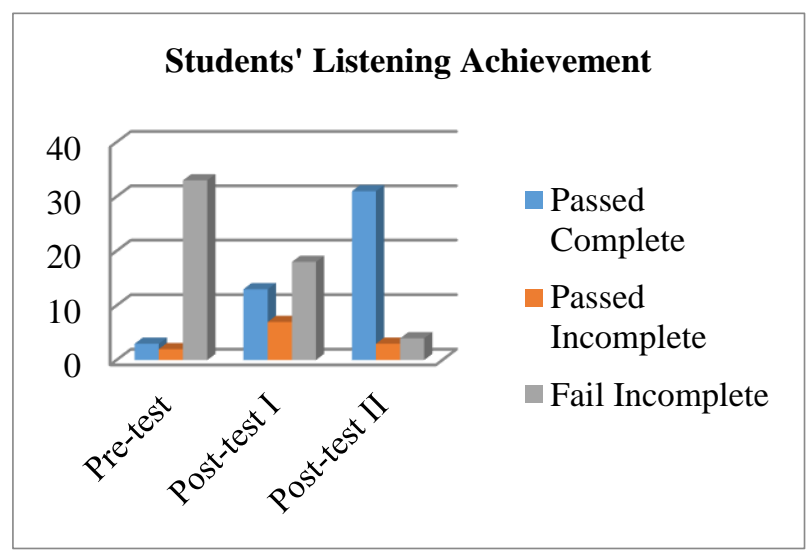

Figure 2. The Improvement of Students' Listening Achievement
As the goal of learning objectives is achieved, the next steps is analyzing the students' satisfactory in learning listening to lectures through TQLR assisted by You Tube videos. Based on the questionairre given, most of the students asserted that they can improve their listening skill by using You Tube Videos; more focus on what they are going to listen. They also get any visuals assistance from the videos which help them to comprehend the listening. They can practice listening itself not only in the listening class but also outside the class wherever and whenever they want with the topic they interested to. It ease them to catch the clues not oly from the audio but also from the speaker' gestures. They also learnt many new vocabularies and how to use it in a sentence correctly. It is also motivated them to learn other lectures topic which indirectly expand their knowledge and experience. In addition, the using of You Tube videos makes them enjoying the teaching learning process itself. Times goes by so fast, and it attracted them to learn listening. This has been supported by Kabooha (2016) who found that using short video made the students motivated and interact to join the teaching activities. The result of the students' answer are summarized in Figure 3.

\section{CONCLUSIONS}

The application of TQLR (tune in, questions, listening, review) strategy aided by You Tube Videos can enhance the students' ability in listening to lecture. The enhancements were proved from the improvement of the students' score, the students' listening ability, and the students' achievement, from cycle to cycle. The TQLR strategy made the students aware to the text they will listen to and prepare themselves to be familiar with any types of text in difference theme. This strategy helps them to concentrate and focus on what type of information they need to gain and getting the main purpose of listening itself.These activities enrich their knowledge, experience, and vocabulary which later will help them in listening activity. The using of You Tube videos is also attract the students' interest in learning listening and adds their skill in looking for clue to get the important information from the oral text to answer the questions given. It is suggested to other lecturers to use theYou Tube videos as media in 


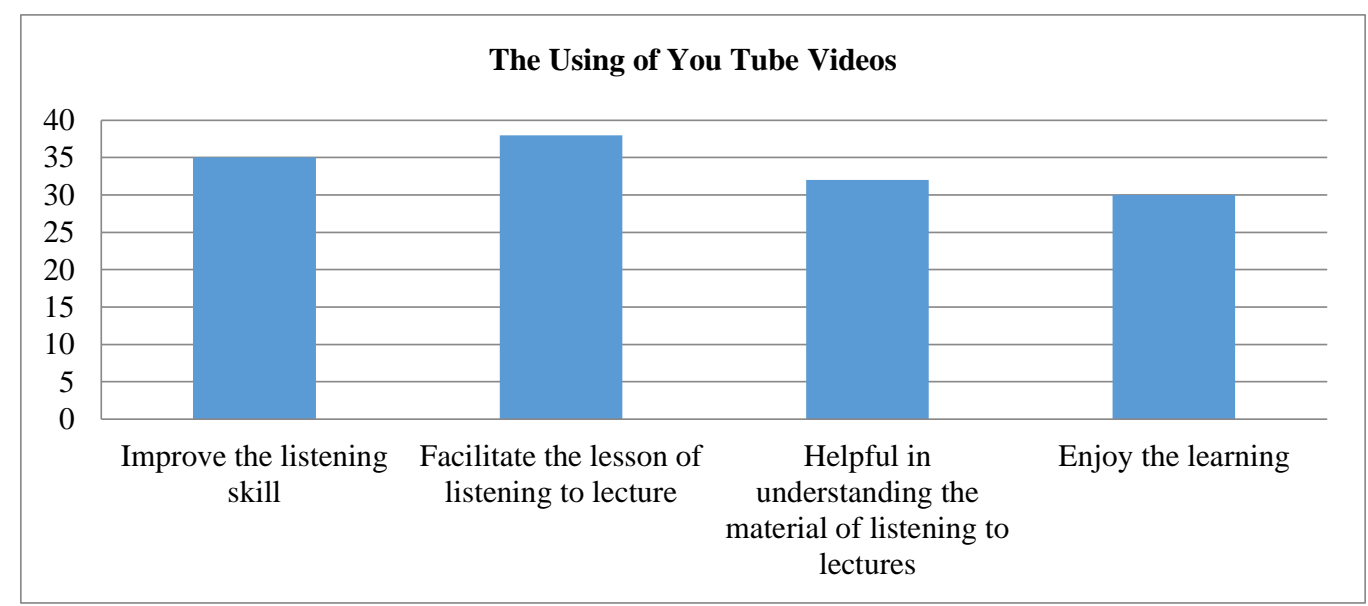

Figure 3. The Students' answer from questionnaire

their teaching process to attract their students interset and motivation in learning, to assure them that it is easy to find a lot of material they need to practice and add their knowledge. For other researcher, the implementation of other social media in teaching learning activity also suggested.

\section{ACKNOWLEDGMENTS}

The researcher would like to thank to (1) Selamat Husni, S.Pd., M.Hum., who has provides advice, critical comments and views in carrying this research; (2) Rini Ekayati, SS., MA., the head of Language Center of UMSU who have given permission to conduct this research; (3) Siswati, S.E., the staff of Language Laboratory who helped the researcher in operating the language laboratory tools; (4) the students of VI-B1 class who participated in this research.

\section{REFERENCES}

[1] Almurashi, W. A. (2016). The effective use of YouTube videos for teaching English language in classrooms as supplementary material at Taibah University in Alula. International Journal of English Language and Linguistics Research, 4(3), 32-47.

[2] Alqahtani, Ebtesam Thabet. (2014). Effectiveness of using You Tube on Enhancing EFL Students' Listening Comprehension Skill. Thesis. Riyadh: Al-Imam Muhammad Ibin Saud Islamic University.

[3] Collier, C. (2016). But What Do I DO?: Strategies From A to W for Multi-Tier Systems of Support. Corwin Press.

[4] Ekayati, R. (2016). Optimalisasi Edmodo Dalam Meningkatkan Kemandirian Belajar dan Kesadaran Berbahasa Mahasiswa Semester VII Pada Mata Kulian LC Di Prodi Pendidikan Bahasa Inggris FKIP UMSU. Laporan Penelitian Teaching Grant, LPPM UMSU. Medan.
[5] Fruarsih, S. (2012). The Effect Of Using TQLR (Tune Question Listen And Review) Strategy Toward Listening Comprehension Of The First Year Students At Junior High School YKPP Dumai (Doctoral dissertation, Universitas Islam Negeri Sultan Syarif Kasim Riau).

[6] Heriyanto, Dwi. (2018). The Effectiveness of Using Youtube for Vocabulary Mastery. ETERNAL (English Teaching Journal). 6. 10.26877/eternal.v6i1.2290.

[7] Herlina, L. (2016). Teaching listening comprehension through TQLR (tune in, question, listen, review) strategy to the twelfth grade students of SMA Negeri 2 Tebing Tinggi. Edukasi: Jurnal Pendidikan dan Pengajaran, 3(1), 53-62.

[8] Kabooha, R. H. (2016). Using Movies in EFL Classrooms: A Study Conducted at the English Language Institute (ELI), King Abdul-Aziz University. English Language Teaching, 9(3), 248-267.

[9] Kabooha, R., \& Elyas, T. (2018). The Effects of YouTube in Multimedia Instruction for Vocabulary Learning: Perceptions of EFL Students and Teachers. English Language Teaching, 11(2), 72-81.

[10] Kelsen, B. (2009). Teaching EFL to the iGeneration: A survey of using YouTube as supplementary material with college EFL students in Taiwan. Call-EJ Online, 10(2), 1-18.

[11]Li, C. (2012). Are they listening better? Supporting EFL college students' DVD video comprehension with advance organizers in a multimedia English Course. Journal of College Teaching and Learning, 9(4), 1-13. https://doi.org/10.19030/tlc.v9i4.7298

[12] Manurung, I. D., \& Sagita, R. (2019, March). Auditory, Intellectually, And Repetition (Air) Learning Model In Listening Procedural Text. 
In Multi-Disciplinary International Conference University of Asahan (No. 1).

[13] Manurung, I. D., Yusriati, Y., \& Hasibuan, S. H. (2019). Pelatihan Menggunakan Media Pembelajaran Bahasa Bagi Guru Madrasah Ibtidaiyah Di Desa Sidodadi Ramunia, Kecamatan Beringin. Journal of Science and Social Development, 2(1), 33-42.

[14] Noviyanti, M., \& Manurung, I. D. (2018). Pengaruh Penerapan Media Audiovisual Terhadap Pengajaran Listening Pada Mahasiswa Jurusan Pendidikan Bahasa Inggris FKIP UMSU. Education and Human Development Journal, 3(2).

[15] Watkins, J., \& Wilkins, M. (2011). Using YouTube in the EFL classroom. Language Education in Asia, 2(1), 113-119. 